\title{
THE MANAGEMENT OF MUSLIM SPIRITUAL TOURISM IN LOMBOK, INDONESIA Opportunities and Challenges
}

\author{
Nashuddin \\ State Institute of Islamic Studies (IAIN) Mataram, Indonesia | nashuddin88@gmail.com
}

\begin{abstract}
Known as "island of thousand mosques", Lombok is increasingly becoming one of the most popular domestic and international tourist destinations in Indonesia. This gives the island ample opportunities to manage and develop its potentials of tourism. However, the way the local government takes up the chance tends to neglect one important aspect of tourism, namely spiritual tourism, a sort of tourism that explores some sacred places or spiritual journey. This article describes three axes of spiritual tourism in Lombok and examines their current state of being as a tourist destination and their challenges to development. This article argues that safety, cleanness and lack of public facilities constitute the main problems of spiritual tourism in Lombok. The problems lay not only on the unsystematic approach of local government policy but also visitors' attitudes of environment preservation, especially among local and domestic tourists. The local government, local community and their leaders must work hand in hand to tackle the problems and rebrand spiritual tourism as popular tourism so it attracts more visitors to come.
\end{abstract}

Keywords: Lombok island, spiritual tourism, Muslim graves, local government.

\section{Introduction}

This article aims to critically examine opportunities and challenges to the management of Muslim spiritual tourism in Lombok. By Muslim spiritual tourism it means visits by Muslims to religious touristic sites, such as graves of saints and sacred mosques that serve not only as touristic but also spiritual destination. Muslims visit those places aim to 
increase their spiritual experience or to observe special rituals while enjoying the places for their beauty and attractiveness. Some of these places are located at the top of hills; others are close to beach. Upon completing their spiritual journey and performing or sending prayer in those places, Muslim visitors go down to the beach to swim or just walk around to enjoy the beautiful scenery. These phenomena can be found in Lombok, such as in Loang Baloq grave, Bintaro grave and Batu Layar grave located in the western coastal area of Lombok known popularly as Senggigi Beach, West Lombok.

Located in the eastern Indonesia, Lombok along with Sumbawa Island forms the current province of West Nusa Tenggara. Lombok becomes one of the most wanted destinations by both domestic and foreign tourists. Many tourists often continue their trip to Lombok from Bali due to its proximity to Bali and its relatively cheap transportation by ferry or plane. It is common to hear the people of Lombok saying that "when you are in Lombok you can see both Bali and Lombok". This is because visitors can see Balinese communities, their temples and their religious activities in Lombok, especially in Mataram, the capital of Lombok, and in West Lombok while also enjoying beautiful places in Lombok.

However, unlike Bali, which has been well-known worldwide as one of the tourist destinations in the world for many years, Lombok just gained its reputation as attractive tourist destination recently. Of the first popular places are three gilis (small islands) in Northwestern Lombok and Senggigi Beach in West Lombok that began attracting visitors for the first time in the 1990s. As these places and others, such as Kuta Beach in South Lombok, Pink Beach in East Lombok and Sendanggile Waterfall and Rinjani Mountain in North Lombok, continue to attract people to come, Lombok also has huge potencies and lucrative market for another form of tourism, especially among Muslims, namely spiritual tourism. In these religiously sacred places, visitors not only enjoy the beautiful environment but also perform rituals in those places. This continues and gains popularity because those places are said to be the sites where Islam was spread firstly arrived or developed.

Unfortunately, not all Muslim spiritual tourism has been well managed despite their prospective economical potencies. Although it emerges earlier than those of general tourism, its current state or condition suggests it does not supersede general tourism in terms of 
economic values and in attracting more visitors. Unfortunately, no serious studies pay attention to this. Studies that systematically explore and examine potencies and challenges of spiritual tourism in Lombok have rarely been conducted despite a number of studies about Lombok. The lack of this management of Muslim spiritual tourism may cause the decrease of visitors. This is the problem that this study will discuss. The first part of this paper highlights spiritual tourism as a new brand of tourism and the common problems associated with it. Next, the paper proposes three examples of places of Muslim spiritual tourism in Lombok and analyzes their current condition, prospects and challenges from the perspective of modern management.

\section{Spiritual Tourism}

Tourism has long been a cornerstone of development in many countries, far beyond other development sectors such as the exploration of limited natural resources. In addition to low cost, tourism as a development sector has higher profit value with smaller threat. Indonesia constitutes one of the countries that attract visitors. Bali, Yogyakarta in Java, Samosir Lake in North Sumatra, Raja Ampat in Papua and Lombok, juts to mention some, are of the most famous tourist destinations. Despite the fact that these destinations gain reputation as the attractive and safe places to visit, problems regarding management and development still persist. These problems are especially concerned with newly-established tourist destination due to many factors. Lack of management, bad facilities and unclean environment are of the common issues. However, these tourist destinations offer great potencies of economic values if properly managed. ${ }^{1}$

Soemardjan views that tourism is a strategic asset to drive the development of the region. ${ }^{2}$ The development of tourism industry, according to him, can press urbanization from rural to urban areas since many tourist destinations are not located in city but in rural or mountainous areas. The efficacy of tourism commonly has three aspects. The first is economic aspect. Tourism provides source of income and taxes. The second is labor aspect. Tourism industry

\footnotetext{
${ }^{1}$ For comparison, see Alex Norman, Spiritual Tourism: Travel and Religious Practice in Western Society (London: Continuum, 2011).

2 Selo Soemardjan, Perkembangan Kebudayaan Nasionaldan Daerab di Indonesia (Yogyakarta: 1977), p. 58.
} 
provides alternative job market and thus can significantly reduce the rate of unemployment. The last aspect is cultural. Because tourism industry often sells genuine of local tradition or culture, they thus help preserve and promote cultural predilection. Unfortunately, these three ,aspects in Indonesian tourism industry seem not to be well organized. Consequently, economic aspects are often hobbled because Indonesian tourism services do not update the current needs. Social aspect is the impact of the weakness of the service, and makes Indonesian tourism stagnant in services and less developed. In cultural aspect, the government, on one hand, has not organized tourism industry with unified form and system of management. The spread of HIV-infected people in tourist areas is one of these indications. Education and community engagement in tourist destination areas should be developed to respond the thriving of tourism market and to prevent to social protests from the surrounding communities who feel alienated economically from tourism industry. The government has not yet organized and established the potential of cultural tourism maximally in various regions of Indonesia. As a plural country with the diversity of local treasures and heritage, Indonesia has a number of attractive places that can be developed as cultural as well as spiritual-religious tourism, especially as considering the existence potential of religious cultures in Indonesia by linking to the historical development of religions in the world.

Postmodern era which is closely related to globalization has impacted in shifting human life, especially changing activity and life patterns, lifestyle and spiritual needs. Nyoman Sri Sumbawa and Ni Wayan Widhiasthini consider these changes as part of the intense competition that occurs in various fields, which give the effect of fatigue on humans. Nyoman and Wayan have asserted that this fatigue effect encourage modern society to seek new form of journey and destination that can fulfill their new needs, namely spiritual tourism. ${ }^{3}$

\footnotetext{
3 See Nyoman Sri Subawa and Ni Wayan Widhiasthini, "Wujud Revitalisasi Wisata Spiritual Sebagai Ekspansi Kapitalisme Pariwisata,” Jurnal Sosiobumaniora, Vol. 15 No. 1 (March 2013), pp. 10-20. In general, the experts on modern psychology hold that the existence of psychological motivation is not given, but the result of interaction with a variety of experiences, environments and cultures. Spiritual element, according to Abraham Maslow, is part of the psychological motivation. The spiritual need depends on the growth and maturity of the individual personality. In modern era, this need is a high demand.
} 
The implementation of this spiritual need closely relate to religious values. These values that are inherent in the history of religion development in the world become part of human social development. Modern people have interest in religious information, sacred discourses and important stories on noble characters. ${ }^{4}$ Modern people begin to lose energy to enjoy their holidays with worldly things. They tend to look for calm places to restore themselves to nature and unite with it.

Spiritual objects such as places of worship, the tombs of the ancestors and traditional ceremonies are important destinations for new form of tourism. ${ }^{5}$ However, the lack of information about these spiritual objects causes the attraction of spiritual tourism underdeveloped. Actually, several countries have managed spiritual tourism professionally. The travel rate of spiritual tourism in those countries has significant amount. ${ }^{6}$ Saudi Arabia is the best example here. One of the most visited places of spiritual tourism for Indonesian Muslims is Saudi Arabia. Indonesian Muslims regularly visit this country to perform a mini pilgrim ('umrah) and spend time and money in two most sacred Islamic places, Mecca and Medina, and may continue to travel to other parts or cities in the Middle East.

Meanwhile, Indonesian Muslims also make in home spiritual visit to a number of sacred places. Some sites have significance for Indonesian people because of beliefs about intangible entities (spirits) outside human dimension. They perform prayer and make meditation in those places. They sit for several hours or even stay several days in mosques or tombs of saints. Some sites are able to call people in large numbers, especially when there is a belief that at some points the relationship between human and other creatures in the world may be connected in these sacred environments.

Unfortunately, the management of this spiritual tourism has been much relied manually on the person, but not much on system. Those who are responsible who inherit visit is usually by the tourists themselves, or spontaneously organized by local community. While

\footnotetext{
${ }^{4}$ See World Tourism Organization, Religious tourism in Asia and the Pacific (Madrid, Spain: World Tourism Organization, 2011).

5 Myra Shackley, Managing Sacred Sites: Service Provision and Visitor Experience (London, New York: Continuum, 2001).

${ }^{6}$ Alex Norman and Carole M. Cusack (eds), Religion, Pilgrimage, and Tourism (Abingdon, Oxon; New York: Routledge, 2015).
} 
popular and larger sites are managed by local government. The best and most popular example of Muslim spiritual tourism in Indonesia, especially in Java, is riarah walisongo (visit to the nine saints who Islamized Java). These saints' graves stretch along northern coastal town in Java, from Surabaya, Gresik, Tuban (East Java) and Kudus and Demak (Central Java), to Cirebon (West Java). Now, newly venerated places include the grave of the late former Indonesian President Abdurrahman Wahid in Jombang, East Java, which is known as the tenth saint.

The Indonesian Ministry of Tourism and Creative Economy predicted that if this spiritual tourism was well managed, it could attract at least 9 million foreign tourists in every year in the last several years. This targeted number of foreign tourists visits is actually a very small target when compared to the number of spiritual tourism destinations throughout regions in Indonesia. In 2009, 2010 and 2012, for example, the number of spiritual tourism was high, reaching 6.9 million foreign tourists in 2009, 7 million foreign tourists in 2010 and nearly 8 million in 2012 (website of the Ministry of Tourism and Creative Economy).

Indonesia has high potential of spiritual tourism. The diversity of religions, ethnics, and the arrival of each religion to many regions in Indonesia has unique meanings for spiritual tourists. Islamic culture in Indonesia is grafted from many cultures. Islamic culture is a hybrid culture influenced by numerous local as well as foreign elements. The culture of Bali Hinduism is different from that of India. The spiritual values of Bali Hinduism cover the intense and complicated diversities. The diversity of each religious journey in Indonesia is valuable treasure as cultural asset of spirituality, connecting all religions in Indonesia that have historical roots in various countries.

\section{Spiritual Tourism in Lombok: The Graves of Saints}

Visits and veneration of grave of saints are most salient form of spiritual tourism in Lombok. There are a number of saint graves, but only three are the most popular, namely Loang Balong, Bintaro and Batu Layar. They are all located in the coastal area of Senggigi Beach, where tourist destination is well established. When people visit these places, they not only send prayer but also continue their journey to nearby beach. This creates their journey spiritually satisfied while conveniently enjoyable. This section will discuss these places, exploring 
their history and current situation. It specifically highlights the management of tourism, its prospects and pitfalls.

\section{Loang Baloq Grave}

The grave of Loang Baloq is located in Bendega of Tanjung Karang coastal village in Ampenan district of Mataram. The grave location is reachable, lying few meters from southern ring road of Mataram. This is an extended area of the city development project that is designed for new establishment of government official building and public facilities. It is only five kilometers from Mataram downtown. ${ }^{7}$ The grave is in the area where public facilities are located. Recently, the government of Mataram built a new coastal park just across the grave area. Next to the west of the park is a center of fish market. Approximately three hundred meters to the north from the grave is Lombok central electricity supplier that supplies most of electricity demand in the island. Several years ago, no house was found in the surrounding area of the grave because this was farming area, except in the east where the local old village was located. At night, the area was empty and dark because of the lack of human activities and housing. But now, new housing complex and settlements are built, rendering the grave more accessible.

Several years ago, visitors mostly came from the surrounding area on foot. Although the infrastructure is now good, no public transportation is available to get to the location. It is probably because this region is quite close and easily accessed. For the people of the surrounding villages, they generally use the traditional transportation, Cidomo (horse-drawn carriage), even some on foot. For the visitors who have motorcycle, they use it, as well as those who have a car.On the other hand, the visitors from remote areas such as Central Lombok and East Lombok, they usually hire public transportation such as car, minibus, and truck.

The term of Loang Baloq grave actually refers to a burial complex in general. In addition to the two sacred tombs, this location is used for the grave of general people, especially for the villagers around the grave, such as the residents of Bendega, Bangsal and Tanjung Karang.

\footnotetext{
7 Todays, Mataram city consists of three districts: Cakranegara, Mataram and Ampenan. Before the existence of southern ring highway of Mataram, the position of the tomb was far away from the settlement of people. It was quiet, therefore the myth nuance was solid.
} 
Loang Baloq is a term from sasak language: Loang means hole, while Baloq or Bebaloq means crocodile. The region was a low, wallowed and watered land. There was, hence, a lot of crocodile passing the region. It is because of the distance of this region to the sea (the Lombok Strait) is only a few meters, therefore the crocodiles often paced. Nowadays, the condition is different because of increasingly crowded situation. ${ }^{8}$ According to the myth believed by some villagers, there was a river flowing from the east to the west (to the coast) which passed the area of this tomb. However, due to the existence of shrine, the flow of the river turns to the north. ${ }^{9}$ Thus, every sacred area has its own myth, and the myth sometimes exaggerates and it is difficult to be accepted by common sense. According to Suparman, opinion spreads out at inhabitants around Loang Baloq is the cemetery is a tomb of Syeikh Gauz Abdurrazak, he is believed that he's from Bagdad and as a preacher of Islam at Lombok Island. Sasak community want to look for blessing by visiting the place whenever they wants. ${ }^{10}$

The tomb is guarded and maintained daily by a caretaker. Due to the location of tomb under the control of Bendega residents, the caretaker is appointed from and by the people of Bendega. The model of designation is based on the consensus of influential community leaders, especially the older people. The caretaker is alternately chosen, so it is not based on legacy systems or descent. Under an unwritten agreement of the local community, the caretaker is chosen from the poorest people. It has certainly a special intent and purpose.The current caretaker is Badri, a senior person that is approximately 70 years old. The sacred tomb in this location is the tomb located in the middle of a big and high banyan tree, with dense foliage and roots in it. However, the roots do not cover the tomb. The tomb is so old to elusive the sources of beginning of the tomb. Nevertheless, it certainly reaches hundreds of years. In addition, in the west of banyan tree is also a sacred tomb and built separately. The tomb also contains a lot of mystery.

Regarding the saint buried in this tomb, no valid data is found. There are many different versions about it. According to an opinion, this tomb belongs to a preacher spreading Islam in Lombok in the

\footnotetext{
${ }^{8}$ Interview with Hj. Idharon in her house in Bendega village (27 November 2014).

${ }^{9}$ Interview with Sukriadion in Loang Baloq (1 December 2014).

${ }^{10}$ Intervie with Suparman, visitor of Loang Balok (23 August 2014).
} 
16th century. The preacher might come from Java as the progressor of Nine Saint (wali songoI), who had mission to spread Islam to the various regions.

In relation to the history of Islam in Lombok, the saint buried here was from the first generation of Islamization period. There are two opinions about the movement of Islamization in Lombok. The first opinion says that Islam entered from the East through Kayangan port in East Lombok in the XIV century brought by the preacher of Arab, Sheikh Nurul Rashid. From Kayangan, he went on a trip through the Java sea and landed at the Cirik port Bayan, and ultimately resided in this northern part of Lombok region. The second opinion says that Islam came from the West through Java island in the sixteenth century brought by Prince Sangapati and Sunan Prapen. ${ }^{11}$ Thus, in the period of Sunan Prapen and the period after him, the wave of Islam spreader to Lombok increased. The saint buried here is most likely the third or fourth generation of Sunan Prapen. Another version says that the buried saint was a sacred person. It is said that once upon time, the saint desappeared in complex of the banyan tree. The tomb then was established here to mark the spot of the saint.

Regarding the name of the sacred-buried saint, no accurate information is found. According to the caretaker of the grave, the name of the sacred-buried saint is Sayyid Ahmad. ${ }^{12}$ He heard this name from the elders. There is no a complete story about it. According to him, he was a saint who had a high level of piety. Some people say that it is the tomb of Sayyed Abdurrahman, where the tomb of this saint was originally located about $2 \mathrm{~km}$ away from the current place, but then for some reason was moved to Loang Baloq. Another version

11 See: Monografi Daerah Nusa Tenggara Barat,Volume I (Jakarta: Department of Education, 1977), p. 33. The evidences are: (a) Two creed sentences defined in the Javanese language, often used in wedding ceremonies. The creed reads in the Javanese language as follows: Weru Insun ora ana pengeran Liane Allah (there is no god but God), Lan Weruh Insun Setubune Muhammad iku utusane Allah (and Mohammad is His Messanger); (b) The existence of literary works using palm leaves in Javanese language contains the teaching of immunity, Sufism and jurisprudence;(c) The existence of a set of gamelan as an accompaniment instrument of Sasak traditional art that is often used in a ceremony such as the Prophet's birthday like sekatenan event in Yogyakarta.(d) The designation of religious instrument taken from Java language, such as Ketib (people who read the speech on Eid prayers), muezzins (people who do azan), and lebe (people who wed someone and lead the prayer).

12 Interview with Badri, the tomb caretaker (12 October 2014). 
says that the name of the saint is Sheikh Wali Sufi. Apparently this is not the name of a person, but a sort of qualified nickname referred to the saint. 'Sheikh' is a term for people of Arab descent. 'Saint' indicates the quality of one's closeness to God. 'Sufi' shows the orientation of religious life that leads to the spiritual life. It is the tomb located in the middle part of the huge banyan tree. There is also a tomb in the west, which is rather small. The existence of this tomb is newer than the main tomb is in the middle.According to the caretaker, the tomb is known as the graveyard of Tiwn child (orphans). It is difficult to obtain further explanation about the child. Many people and pilgrims even do not know.

The separate tombe built on the west is believed to be the tomb of "Sea Datu". According to the belief of local communities, this tomb has also sanctity, especially for the fishermen. Whenever they encounter trouble while sailing to look for fish in the sea, such as slammed by the waves or strong winds threatening their life, they ask God to be saved, and then promised to visit the tomb of Sea Datu later. The rescue then soon comes, and the circumstance goes well. As a result, they are able to go home safely. ${ }^{13}$

Every Sunday, people from all sides of Lombok Island, even from other regions, visit the grave. They generally come in groups by chartering public transport. In addition to Sunday, the months of pilgrimage and Eid Fitri as well as Eid Topat are the most crowded time. The number of visitors daily, apart from Sunday, is not many. On average, there are approximately 50 people a day. But the number increases on Sunday, from 500 to 750 people. However, the most crowded period is on Topat Eid, as the pilgrims up to thousands people. ${ }^{14}$ The pilgrims come from all sides of the island and have various background of life. Their professions are varied, dominated by the fishermen, farmers or agricultural laborers, traders, and informal sector workers.

At the present, there are many traces of bond in the banyan tree made by pilgrims. There are no accurate data about the beginning of bond. The belief of some pilgrims is that if he/she has particular intent, he/she will make bond in the tree, either from plastic, yarn, or

\footnotetext{
13 Interview with Sukriadion in Loang Baloq graveyard (30 November 2014).

14 This number is the estimation of research team, compiled from the observations during the study and the results of interviews with traders around the tomb.
} 
rags, while promising that he/she will visit the tomb again to release the bond as the intent is done well. The amount of the bonds created by the pilgrims cannot be counted. They are so many disturbing the cleanliness of the location and the beauty of the trees. Maybe it is the reason that there is a written board: No Binding the Tree, meaning: prohibited to make bond in the tree.

The facilities in this grave are: 2 units of remembrance (drikr) rooms, toilet, and 4 units of berugaq (rest board). No praying room in this area, therefore if the pilgrims want to pray, they usually do it in the berugaq. In general, berugaq is used by visitors to eat together with their family. When there is no visitor, children use berugaq as playground.

The daily management of this tomb is handled by the caretaker, namely Mr. Badri (70 years old). He is responsible for the cleanliness and the security of the grave. Meanwhile the general management is handled by all residents of Bendega village coordinated by the headman and the Bendega mosque managers. There are several charity boxes at the grave site with its clear allocation respectively. Some are for grave management, caretaker and prosperity of the mosque. The total revenue on certain days is not high, but on harvest time or other special day is high.

\section{Bintaro Grave}

Bintaro Grave is in Bintaro Pondokperasi, North Ampenan, Mataram. This grave is actually a common cemetery, in which local residents always bury the corpse in it. There is a burial complex of Chinese descent citizens in the south of this grave. The people of Arabs descent are also buried here. The text written in the tombstone shows Arabian clans, such as: Al-Idrus, Al-Jufri, Assegaf, Bagis, AlKaf, Sahab, Al-Syatri, Aqil, and Habsy. Since hundreds years ago, a lot of Arab descent have been living in the district of Ampenan, namely the Arab village. However, in the outside of Arab village, there are also people of Arab descent, including those in Bintaro. Based on Amat opinion, the cemetery is one of spritual tourist destinations. It tells us about the moslem scholar (ulamā) from Hadramaut who came hundreds years ago (1865) to complete islamization at Lombok Island. He did completion of islamization because islam that's received by moslem on that time is not completed yet. ${ }^{15}$

\footnotetext{
${ }^{15}$ Interview with Amat, one Ampenan Inhabitants (23 August 2014).
} 
There are some sacred tombs, especially 3 old tombs located in the particular building. According to the local people, the tombs belong to important saint who have contributed in spreading Islam in Lombok. The tombs are treated differently than other tombs, that there is a net surrounding them. According to the caretaker, the people are: Sayyid Abdullah Al-Badawi (eastern tomb), Syarifah Zahra Al-Ethiopia (western tomb), Sayyid Ahmad bin Hussein Mulachela (northern tomb). These names are derived from the present grave caretaker, in which he got the names from his predecessors. ${ }^{16}$ They are the people who play a role in spreading and developing Islam in Lombok. These tombs are a magnet for the pilgrims to come.

These three main tombs are in a complex of buildings measuring 9 $\mathrm{x} 10$ meters. In addition to these tombs, there are a number of tombs in the building, but no information about the names of the buried. They were might be the heroes for the local people.

The outside of building is a public cemetery. There is also a sacred tomb, namely Saleh Sungkar. The tomb is located on the south side of the building, approximately 10 meters. Saleh Sungkar was not a classical saint, because he passed away about 50 years ago. He was an Arab descent from Salatiga, Central Java, who was known as an activist and populist politician. He had led the Arab Association of Indonesia (PAI) in Lombok. He was not fanatics on Arabic descent. He gave respect to the struggle idea of Bung Karno (the first president of Indonesia), although eventually he was active in the party of Masyumi. He was a respected politician, because he breaved to put indigenous people in the House of Representatives at that time. He was one of the important people in improving governance of the newly independent republic in Lombok. When a new House of Representatives was formed in Lombok, Saleh planned to make a session of representatives which was considered as a way to alleviate the suffering of the people of Lombok in the early days of independence.

The session urged the stop of gambling activities, and also urged the merchants-particularly of the Chinese descents-to stop hoarding goods that benefit only on a small group and at the same time torment other people. He also condemned Lombok elites or nobility known as feudalistic landlords. At least, it is the general description of the personality of Saleh Sungkar. Because of his manner,

${ }^{16}$ Interview with H. Ali Bahweres in Bintaro (8 December 2014). 
eventually he had to face a tragic fate. He was kidnapped by a group of people, supposedly from military personnel who were sent by officers and political opponents. They did not agree with the agenda of the session of people representatives. Saleh was considered as the initiator, therefore he was victimized. He was beaten and killed. His body was then dumped. This incident was in 1952. About a month later his body was discovered in ruins, and his bones buried in the Bintaro grave. There is also a separate tomb for part of his body. ${ }^{17}$ The story about the life and assassination of Saleh Sungkar can be easily obtained especially from the seniors of Arab descent.

The Bintaro grave caretaker at the present is Ali Bahweres. He has been caretaker for long time, which earlier held by his parent and predecessors. The status of caretaker is almost always held by someone in his family. It has happened since the first generations. He is the fifth line of his family who is in charge of guarding the grave. The following chart shows the successive caretaker: ${ }^{18}$

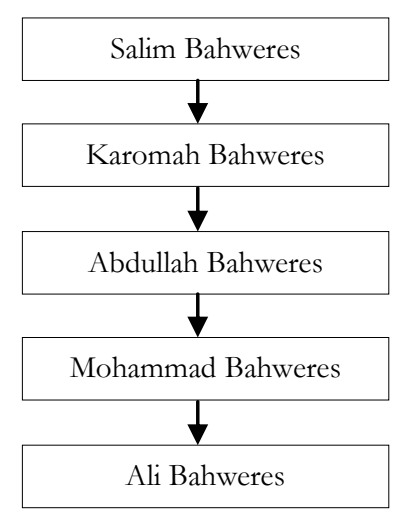

The management of this grave is held by the caretaker and local community leaders. The result of charity box is recorded and then used for the cost of grave care, electricity and other necessities. Due to limited funds, the complex of grave was fixed by the government at the last fasting month, in the form of road construction. The building of main tomb was also grounded by ceramics which was previously

\footnotetext{
17 See magazine: Kilas, "Nasib Tragis dan Kisah Cinta Saleh Sungkar", No. 10/year I/July-Agust 2003, p. 13.

${ }^{18}$ Interview with H. Ali Bahweres in Bintaro (8 December 2014).
} 
cement floors. Thus, the physical condition of the tomb is now good and may add to the comfort for the pilgrims.

There are always pilgrims, especially on Wednesdays, Saturdays and Sundays. The busiest months are Rajab, Sha'ban and Maulud, as well as on the departure of hajj. A week after Idul Fitri is also crowded. The local traders in the complex of grave are happy as many pilgrims come. In addition, if there is a religious ritual, the traders are often invited to join together to enjoy a meal brought by the pilgrims. ${ }^{19}$ With its facilities and atmosphere, the Bintaro grave may be called the most clean grave than other two graves.

\section{Batu Layar Grave}

Similar to the two previous graves, the Batu Layar grave is located near the highway so easily visited by the pilgrims. The grave is located in the village of Batu Layar subdistrict, West Lombok, about $15 \mathrm{~km}$ north of Mataram city. The grave complex faces directly to the beach, which has a special attraction for the visitors. Its position jutted out and in the bend of the road to Senggigi, the main area of Lombok tourism.

The population of Batu Layar is about 100 families with the majority are farmers, and some are fishermen.Concerning religious affiliation, $99 \%$ is Muslims and 1\% is Hindus. Due to the location of village which is near to the beach and far away from the hustle of city, the religious life among muslim community is fanatic, especially on the events of Islamic days.

The wide-scale of the complex is about 1.5 hectares, which becomes the center of public cemetery for Batu Layar people. The position of the grave is about 20 meters above sea level and located just a few meters from the beach. When viewed from the top, the shape of this complex like the tip of a sailboat, with many rocks around. That is the reason why this area is called Batu Layar (Screen Stone). One of the respondents said that there was a big rock on the edge of the coast, then affected by the waves as if to go sailing. The stone was inhabited by a saint derived from another region, coming to this island for Islamic mission. The people then called Batu Layar. ${ }^{20}$

\footnotetext{
${ }^{19}$ Interview with Aminah (44 years old) and Sulkiyah (39 years old). Both are traders in the complex of Bintaro tomb (12 December 2014).

${ }^{20}$ Interview with H. Tahir in Batu Layar (3 December 2014).
} 
The road to this area is very nice because it is part of the main highway in Lombok.A few kilometers of the north side of Batu Layar is the area of Senggigi and Kerandangan, where a number of hotels stand, so that the flow of tourism vehicles such as taxis is crowded, especially on holidays. The pilgrims who come from Mataram and the surrounding areas generally use two-wheeled vehicles or public transportation.If using public transportation, from Mandalika bus station Mataram one should lead to Kebonrowek market. Then he/she use another public transportation to Senggigi, and could reach Batu Layar district. The pilgrims from out of town generally use a vihicle such as minivans or trucks. They come usually in groups with dozens of members/congregation and led by a religious leader.

The condition of the tomb is good, located in a house building measuring $5 \times 6 \mathrm{~m}$, while the tomb is located in the middle of the building with the size of $2 \times 2.5 \mathrm{~m}^{2}$. On the tombs are two gravestones and white curtain of approximately $1.5 \mathrm{~m}^{2}$ in height. The condition of the curtain is quite damaged and faded.The pilgrims carry out the rituals in the inside of this building, so when the visitors are many, this place is crowded.

The grave is located above the plateau of about 6 meters from the road surface. The frangipani trees and other big tress grow around the grave. Behind the grave complex is a widely coconut and banana garden, so that the condition of the grave remains cool. The facilities around the grave are two terrace buildings with each measuring about $3 \times 5$ meters, that are generally used by pilgrims to take rest. Even for the pilgrims who come from a distant region, the terrace is used for lunch after religious ritual at the tomb. However, there is no toilet in this complex, because of its high position above sea level. There is also no mosque. Interestingly, the grave is rather large and there is a number of trees, so the visitors may use it as a place to sit and relax.

The grave is guarded daily by the caretaker, namely H. Mustafa (64 years old). He has became caretaker since 1975 until now, a fairly long period. The previous caretaker was his parents, or in other words, he became the caretaker by the system of hereditary. In the previous period, the grandmother of Mustafa is also a caretaker of this grave, and therefore she was buried in this complex, below the main building of the sacred tomb. ${ }^{21}$

${ }^{21}$ Interview with H. Mustofa in Batu Layar graveyard (3 December 2014). 
According to various sources, the sacred saint in this tomb is Duhri Sayyid Al-Haddad Al-Hadrami. He was a prominent saint in spreading Islam and stayed in Lombok, but not for long time. Then he continued his journey to do his mission. No one knows about the exact time of his life. Even the local communities and the pilgrims do not know much about the name of the saint. Generally, they only know him as the saint coming from Baghdad. In addition to the main tomb, there is also a sacred tomb at the rear side. The local people call the tomb Lebai Sandar. There was a concave stone like container that could be occupied by water. The various myths about the rock developed. Later it was stolen. There is no accurate data describing the existence of this person. Some say that Lebai Sandar is another name of Duhri Sayyid Al-Haddad. In the Ampenan district, there is a mosque called Lebai Sandar whose tomb is located in Batu Layar. ${ }^{22}$ The people have believed that these saints are pious people, who deserve the honor because of their important services.

Batu Layar grave is usually crowded with the pilgrims in certain months such as Maulid, Sha'ban, Shawwal, Dhu al-Hijjah, and in the months of harvest crops. The most crowded day is Sunday, while on other days the pilgrims are rare as about one or two groups. Every Sunday, the amount of visitors is no less than three hundred people.

On certain days, the pilgrims are many and booming, especially during Topat Eid. The region of Batu Layar annually becomes the center of celebration of Topat Eid in Lombok. On that 8th day of the Eid Fitri, the region of Batu Layar is filled with flocks of people from different regions, especially from Mataram city and West Lombok. Since the last few years, the local government has developed this kind of tourism. The government officials such as the governor and mayor of West Lombok have great attention to this tradition, not only due to the preservation of Islamic culture but also to help the rise of tourism in Lombok. The purpose of visitor is different. But they usually come to that place for one main purpose namely spritual tourism.23 This spritual tourism is also followed or accompanied by other sacred local tradition such as ngurisang (hair cut of baby). Ngurisang is one of sasak

\footnotetext{
22 Interview with Gunawan in Mataram (8 December 2014).

${ }^{23}$ Interview with Mite (12 January 2015).
} 
tribe tradition to throw away hair brought by children from their mother's stomach. ${ }^{24}$

Lombok is well-known as "the island of thousand mosque". This signifies the strong influence of Islam on the island. Many argue that spiritual tourism is synonymous to cultural tourism. Others consider cultural tourism as spiritual tourism. In fact, these two opinions are interrelated. When viewed from the terminology of spiritual values and cultural values, the relationship between spiritual tourism and cultural tourism is closely related because they have synergy in certain ways. The spiritual values are acculturation between the values of religion and local community, while cultural values are the values formed by acculturation of religion, culture, traditions and geographical conditions.

Thus, the spiritual values have strong inherent in local culture and vice versa. The close relationship between spiritual tourism and cultural tourism forms the meaning of the spiritual tourism as more than just attraction but also looking for relationship between spiritual values and community culture. Spiritual tourism explores the values of culture in which spirituality is born and developed. Spiritual tourism even looks at how each spiritual value may endure to modern era. The spiritual values which are blended with culture take shape in numerous activities, such as the ceremony of local traditions, religious rites and others. Those values sometimes have mystical aspects. They are in modern world often considered illogical and unreal. However, that is the attraction of spiritual tourism, because spirituality is closely related to belief and faith which are unthinkable.

At the end of 2013, there was Hanum Rais' movie entitled 99 Cahaya di Langit Eropa. The movie describes European journey as interesting spiritual tourism filled by spiritual values. This movie tells about a female Muslim made Islamic trip in Europe. This trip requires extensive information about the history of Islam and Islam's relationship with the European community in its first era. In the movie, the information about Islamic history in Europe was scripted in accidental encounter with certain people who describe the architecture of European relations with Islam, or explain how Islamic civilizations have given interesting buildings in Europe. While in real life, spiritual tourism is also needed to be scripted, not through accidental encounter

${ }^{24}$ Ibid. 
but detailed and comprehensive historical explanation, which is able to evoke a sense of wonder to Islamic journey.

Spiritual tourism has been initiated by Islam through pilgrimage trip (hajj) to Mecca. Hajj is designed with philosophical meanings in each location. There are many mystical aspects in hajj that may make the faith of a Muslim increase or reduce. There are many rites in bajj that seem to be irrational. Those all are exciting! People who have performed hajj and who have not yet love those illogical aspects. Many people define hajj mabrür as hajj filled by certain miracles along the process of worship.

Is haij as spiritual tourism rejected by modern people as unscientific and illogical? The answer is 'no', because spiritual tourism is certainly related to unveiled things. However, many Islamic scholars are worry about Islamic spiritual tourism tends to polytheism. It is a fundamental worry, especially as Islam in Indonesia, Malaysia, Pakistan and Arab has dark ages dealing with superstition, heresy and superstition. Therefore, to develop spiritual tourism in Islam needs deliberate design and involve many stakeholders in order this spiritual tourism does not trap on preservation of superstition, beresy and superstition.

The spiritual tourism of Indonesian Islam has been long time, but has not been designed well due to trap on possibilities of superstition, beresy and superstition. Only by examining the history of Indonesian Islam, understanding the relationship between regions in the development of Islam, understanding the spiritual values along with the process throughout the history of Islam, Islamic spiritual tourism will return to basic, return to long contemplation of the Muslims on its fundamental history.

Decentralization and regional autonomy are established as a new policy to uplift social welfare. This policy gives ample spaces for regional governments to empower people and increase social service. One of the ways to realize this objective is to improve tourism sectors. According to World Trade Organization (WTO), tourism industries open up to 230 million of job opportunities and contribute billions of US dollars revenues in many countries.

In 1995, Indonesia gained 15 billion USD in foreign exchange from wood, textile and oil and gas exports. Tourism also contributed to this revenue. According to State Statistical Bureau (BPS), since 2010 Indonesia has recorded the increasing number of foreign tourist visit up to $10 \%$ each year. In addition to add the state revenue from foreign 
exchange, tourism also contributes domestic revenue as many tourists use local hotels for accommodation and eat at local restaurants. They may also purchase local products as well. This local sale may include souvenirs and other hand-made products, handicrafts made by local people. Moreover, tourism also spurs the growth local travel agents that provide affordable travel packages and other tourist needs when they visit particular areas.

Indonesia had a unique experience from tourism industries. In 1997, when economic crises hit Asian countries, Indonesia was one of the countries in this region that received worse economical impacts. But the prospect of tourism had helped it to recover soon. At least, tourism sectors had saved it from becoming bankrupt. For that reason, the government paid more attention to tourism sector. The government, for example, issued Regulation No. 25/2000 regarding National Plan Program where tourism sector should not only assist economic recovery but promote Indonesia to international community as the best and safe place to visit. The regulation also emphasized that tourism must become a sector that pushed forward people's economy. This project was known as community-based tourism development.

Community-based tourism (CBT) is development of tourist destination through local people empowerment. There are three programs that can support the concept of CBT: adventure travel, cultural tourism and eco-tourism. Adventure travel is a kind of travel that explores inland areas that cannot be easily reached except by specific means of transportation and travel program. Cultural tourism offers tourist destination that has cultural significance. It emphasized not only pleasure for tourism and travel but also learning from other cultures. Meanwhile, eco-tourism put special emphasis on tourism that preserve environment. In other words, eco-tourism is meant to create tourism that is not harmful for environment. It is in this context of community based tourism that spiritual tourism can be developed.

What needs to be developed further is to arrange or establish new approaches to the realization of CBT. Nicole Hauser argues that in order CBT to be successful it should give attention to people who are not involved in the project but will still gain benefit from it. ${ }^{25}$ This means that tourism on the basis of CBT must give benefit to the

\footnotetext{
25 See Nicole Hausler, Community based Tourism (CBT) What Works and What Does not Work? Drawing on Experiences in South America and Asia, p. 21, from URL: www.mascountour.info (Accessed on 28 August 2000).
} 
greater people despite the fact that they may not part of it. It is economic sharing and distribution that CBT must take into serious consideration if it wants to be a successful tourism project. This process of social and economic empowerment of the people affected either directly or indirectly is believed to affect politics at the local level and promote democracy.

How does the policy of decentralization affect tourism sector in Lombok? According to the research on tourism in Lombok, conducted by Alhilal Furqan and Ahmad Puad Mat Som, decentralization has helped tourism grow significantly. They stated that local people and public figures were very concern about tourism sector and decentralization proved to be an effective policy.26 Decentralization gave regional and local government a new responsibility to be able to manage tourism that fit best to the local wisdom and convention and give economical advantage to the people. Tourism is seen by the people as an important sector that can generate income and create prosperity. More importantly, the research argues, good tourism is the one that also stimulates the development and the growth of other sectors such as farming, fishing and create job opportunities for the local people, as they are concerned.

As farming sector is important in Lombok, the policy on tourism is expected to stimulate the sector of farming as well. The new regency of North Lombok, for example, wants to integrate tourism and farming because the region is rich in farming sector. This research shows that tourism is the second priority after farming. By integrating these two sectors the local government envisions the growth of tourism along with farming industries.

The support of the regional government to tourism can be seen from the budget allocated for the development of this sector. Head of Regional Revenue Bureau of West Nusa Tenggara stated that the government has allocated 2 billion IDR (USD 2 millions) to support the establishment of structure and facilities that can promote tourism. The budget was taken from the special allocation-oriented budget (dana alokasi khusus). Decentralization thus helps the local government like in Lombok to manage tourism in more convenient ways including in using the state budget to develop it. They do not have an advance

\footnotetext{
26 Alhilal Furqan and Ahmad Puad Mat Som, "Effects of Decentralization Policy on Island Destination in Indonesia," World Applied Sciences Journal, 10 - Special Issue of Tourism and Hospitality, 2010.
} 
approval from the central government to manage their own policy in tourism sector.

In the course of the decentralization, the volume of foreign tourist visits to Lombok increased significantly. The exception was only in 2003 after a series of mass riots that demolish tourist destination in Senggigi. The riot was influenced by general gathering of Islamic solidarity against Muslim massacre in Mollucas. The tourism sector in Lombok also suffered tremendously following the Bali Bombing in 2002. However, these are external factors, not internal mismanagement of tourism.

In order to make decentralization useful and effective to support tourism, several ways must be taken. First, this needs effective coordination and cooperation between central and local government. What needs to be done by the central government is to issue regulation that authorizes the local government to be creative in managing tourism sectors and industries. For the local government, the decentralization in tourism sector means that they must become a good manager to manage tourism sector. No less importantly is the role of the local people. They have to support the local government policy on tourism by, for instance, providing safe and convenient environment for tourism. They also need to preserve their environment, restore ancient building or unique sacred places to attract more and more tourists to come for visit.

After the Reform era, following the downfall of Suharto regime, the form of decentralization can be fully implemented upon the issuance the law of local autonomy. Although in the reality this implementation of this law still faces hindrances, decentralization is the best approach to develop tourism sector in local and regional levels, such as in Lombok.

\section{The Challenges for Spiritual Travel Actors}

The biggest challenge to carry out spiritual tourism is Human Resources (HR). The management of spiritual tourism which will involve a lot of local people, requires socialization and counseling approaches intensively. The greatest difficulty in developing cultural tourism is to build the mindset of local communities. However, if we are succed in managing these difficulties, the public will be grateful for the opportunities they get. 
Another challenge is the relationship of cooperation with the local governments. The regulation no. 22/1999 which is enhanced in the regulation no. 32/2003 about regional autonomy has provided great opportunities for each region to develop itself including the sector of tourism. However, the problem in spiritual tourism is concerning the sector across the regions. While todays, the cultural tourism belongs to localization per area. Therefore, it needs a specific endeavour to build inter-regional cooperation to undertake a more comprehensive spiritual tourism.

The other challenge is about the historical understanding of spiritual sites. This understanding is still poor and undeveloped. A depth study and interesting presentation (ears cathing) of spiritual stories are needed. The failure of the development of spiritual tourism today lies in the lack of historical information about any spiritual sites. Recognized or not, the tour guide of spiritual tourism today is charged to the guard of the mosque, grave caretaker, and guard of the site, so that the information provided is often stuck in superstitions. Instead of providing real information, sometimes they give the issues of idolatry. At this level, spiritual tourism loses its soul.

The other fundamental challenges is to build awareness of spiritual tourism among the people of Indonesia. Although it starts to be interested, the package and the offer of spiritual tourism in Indonesia are still not the option to be chosen. Conversely, the spiritual tourism to foreign countries is increasingly high.

\section{Conclusion}

West Lombok Nusa Tenggara has many spritual destination to visit. Spritual destination for Sasak tribe has at least two meanings; first, go sight seeing to decrease burden or free from daily routinity, secondly, the spritual destination was aimed at remembering efforts of many moslem people who had preached islam at Lombok hundreds years ago. The tombs or cemeteries of those people were visited and then called with spritual tourism. There are three popular spritual destinations at west Lombok; Loang Baloq, Bintaro and Batu Layar. Many people come to that place to symbolize two relations of human being namely good relation with God and good relation with other.

Based on reality that those spritual tourims destination are always crowd of people any time, West Lombok Government should to manage those sacred places as well as possible. The best way to realize 
it is by cooperating of west Lombok Society with local government. Management of those spritual touristdestination is directed to planning, organizing, actuating and controlling of human and nonhuman resource to take part in taking care those sacred places existence from any irresponsible hand for the sake of local society in one side and for othe visitor, foreigner on the other side. []

\section{References}

\section{Books and Articles}

Alecu, I.C. "Epistemological Aspects of Religious Tourism in Rural Areas." International Journal of Business, Management and Social Sciences, Vol. 2, No. 3, 2010.

Ambary, Hasan Muarif. Menemukan Peradaban: JejakArkeologis dan Historis Islam Indonesia. Jakarta: Pusat Penelitian Arkeologi Nasional, 1998.

Furqan, Alhilal and Ahmad Puad Mat Som. "Effects of Decentralization Policy on Island Destination in Indonesia." World Applied Sciences Journal. 10 - Special Issue of Tourism and Hospitality, 2010.

Garrod, Brian. Tourism Marketing: A Collaborative Approach. N.p.: Channel View Publications, 2005.

Hausler, Nicole. "Community based Tourism (CBT) What Works and What Does not Work? Drawing on Experiences in South America and Asia." www.mascountour.info

Norman, Alex and Carole M. Cusack (eds). Religion, Pilgrimage, and Tourism. Abingdon. Oxon, New York: Routledge, 2015.

Norman, Alex. Spiritual Tourism: Travel and Religious Practice in Western Society. London: Continuum, 2011.

Rais, Hanum Salsabila. 99 Cahaya di Langit Eropa. Jakarta: Gramedia, 2011.

Shackley, Myra. Managing Sacred Sites: Service Provision and Visitor Experience. London, New York: Continuum, 2001. 
Nashuddin

Sjadzili, Ah. Fawaid. "Mengunjungi Tempat Suci; Ragam Motivasi Wisata Religious." Jumal Karsa, Vol XVIII No. 2 (October 2010).

Soemardjan, Selo. Perkembangan Kebudayaan Nasional dan Daerab di Indonesia. Yogyakarta, 1977.

Subawa, Nyoman Sri Subawa and Ni Wayan Widhiasthini. "Wujud Revitalisasi Wisata Spiritual Sebagai Ekspansi Kapitalisme Pariwisata." Jurnal Sosiobumaniora, Vol. 15 No. 1 (March 2013).

Timothy, Dallen J. and Daniel H. Olsen (eds). Tourism, Religion and Spiritual Journeys. New York: Routledge, 2006.

World Tourism Organization. Religious tourism in Asia and the Pacific. Madrid, Spain: World Tourism Organization, 2011.

Zahwu, Abu. Alhadis wal Muhaddisun. Beirut: Dar el Fikr, 1989. 